DE DE GRUYTER

OPEN

Polish Cartographical Review

Vol. 48, 2016, no. 1, pp. 29-40

DOI: $10.1515 /$ pcr-2016-0004

KATARZYNA SŁOMSKA, JOLANTA KORYCKA-SKORUPA

Department of Geoinformatics, Cartography and Remote Sensing

Faculty of Geography and Regional Studies, University of Warsaw

slomska.k@gmail.com, j.skorupa@uw.edu.pl

\title{
The teaching of cartography and topography in the Polish primary school
}

\begin{abstract}
The authors present a content analysis of the selected textbooks for teaching the natural science in the Polish primary school in the scope of cartography and topography. Two series of textbooks edited by the Nowa Era publishing house and approved by the Ministry of National Education are used by the authors. The main aim of this analysis is to determine whether the textbooks meet the requirements of the new core curriculum. The psychological aspects that may cause the difficulties in learning the natural science for students of grades 4 through 6 of the primary school are also discussed.

The contents of textbooks are absorbed by the students in varying degrees. It is important, therefore, to take into account the psychological aspects of the students' learning process and draw attention to the difficulties that may arise in the course of grade 4-6 instruction. Among them there are, inter alia, the difficulties in using a map scale, some problems with imagining the actual distances and areas, a height above the sea level and the relative heights, as well as the issues related to the students' abilities to read a drawing of contour lines.

In the process of natural science education in the primary school, it is very important to develop the children's abstract thinking, which causes the stimulation of their spatial imagination. The various types of teaching aids, which can be helpful for the both groups, as for the teachers, so for the students, are discussed in this article. These are the atlases, models, interactive teaching aids, books and educational games.

The analysis introduced in this article allows for a critical evaluation of the textbooks for primary school from the point of view of their content complacencies on cartography and topography with the new core curriculum.

Teaching the bases of cartography and topography from an early age is very important, but developing the ability to use a map requires the continuous exercises. Working with a map helps to develop not only the practical skills, but also the students' attitudes having a positive impact on the development of such qualities as conscientiousness, accuracy and patience; it also has an invaluable impact on the students' spatial imagination.
\end{abstract}

Keywords: core curriculum, teaching aids, didactics of natural science, cartography, topography

\section{Introduction}

In the school year of $2009 / 2010$, the educational reform, resulted in the core curriculum change of school education, took place in Poland under the Regulation of the Ministry of National Education. Among other things, the changes related to the subject called "natural science", taught in primary school; the main goals of those changes were the equal educational opportunities and improvement of educational quality. The new textbooks for natural science appeared in schools in 2012, when the children, who were covered by this reform, became the students of the fourth grade. The full sets of textbooks for grades 4 through 6 were published in 2014. Due to the lowering the school age to six years of old, the students of the fourth grade are 9 or 10 year-old children now, while the students at age of 11 or 12 finish the natural science education in primary school.

An important need, therefore, seems to be the analysis of current state of the knowledge transmitted from teacher to student in primary school. For the purposes of this study, the cartographical and topographical contents included to the textbooks for natural science have been evaluated. Two sets of textbooks issued by the 
Nowa Era publishing house: Na tropach przyrody (On the trails of nature) and Tajemnice przyrody (The secrets of nature) were hosen and their contents were analised and compared. Another reason for choosing The New Era Publishing House was the atlas for natural science issued by the same publisher.

The contents of the textbooks are absorbed by the students in varying degrees. So, it seems relevant to discuss the psychological aspects of students' knowledge acquisition and to draw the attention to the difficulties that may occur in the process of teaching in grades 4 through 6 . One should, therefore, review also the teaching aids and didactical solutions supporting teaching and learning.

\section{The importance of teaching the basics of cartography and topography}

The natural science classes can be an opportunity of getting to know the surrounding objects and phenomena, as well as an occasion to help the students in recognizing the geographical space. The most important thing, however, is to create the students' attitudes of being "the explorers of the world" - in a way that gives them a possibility to observe constantly and be able to indicate the interdependence in the natural world. One of the aids to support these activities is a map that "allows you to exceed the normal range of vision" (W. Ostrowski 1990, p. 128). The teacher's task is to show to the students how to work with a map.

Learning the bases of cartography and topography gives the opportunities to a young man to get to know the world on his own. Therefore, the base for his further education should be transmitted to him in the best possible way, emphasizing the practical applications of the acquired knowledge. We are talking about skills such as determining the geographical directions, using a compass or GPS, map reading and map use.

Map is a widely applicable tool in teaching natural science because the ability of using a map is required at the later stages of education. According to M. Wilczyńska-Wołoszyn (1990, p. 143) "these elementary skills form the foundation, on which a whole system of assimilating the geographical knowledge with the help of maps will be gradually built then".
Thanks to the teacher's tips, the student's work with a map can be independent.

Undoubtedly, an exemplary teaching aid was and now is the textbook written by $\mathrm{E}$. Romer (1908) titled Geografia dla klasy pierwszej szkół średnich z atlasem geograficznym (The Geography for the first grade of high school with the geographical atlas). The author tried to lead a student so, that - if it was possible - he should come to the knowledge on his/her own.

The work with a map may be difficult for the students of the grades 4 through 6 , because it is a symbolic image of reality. In the seventies od the 20th century, the research on this topic was led by Z. Batorowicz (1971), and then, the problems that may occur during the process of work with a map were described by W. Ostrowski (1990). The authors, discussing the map properties, agreed, listing the functions of a map: practical (spatial orientation), cognitive (visual analysis) and educational (map interpretation). Both the authors stressed a special role of the contour maps at this stage of natural science education.

The cognitive and educational functions practically form a unity, because the interpretation of a map without its visual analysis is not possible. W. Ostrowski (1990, p. 141) pointed out, that these two processes always occur together and separate discussion on each of them "may be only conventional".

\section{Psychological aspects and difficulties of teaching in the grades 4 through 6}

\subsection{The elements of functional psychology}

The Piaget's theory is often described in the literature. His research had a major impact on education. It proved that "the children's intelligence is qualitatively different from the adult's one" (A. Birch, T. Malim 2001, p. 52). The teachers must take into account a stage of development at which a child is. The ability to use the concepts and learning by doing should also be taken into consideration. The new issues should be connected to the old ones, those, a child has already known and experienced, and then, it is easier for him to understand them. In addition, the introduction of concepts should be done by using small and specific objects to shape the abstract thinking gradually. 
From 7 to $10-12$ years of age, a child goes from the stage of concrete operations to the stage of formal operations. The ability of abstract reasoning (without any reference to the specific objects or events), dependent detecting and problem-solving "in mind" (A. Birch, T. Malim 2001) appear then. At this stage the concepts of space, number and volume also appear. A child begins to understand the relations between the whole and the parts, can make the classifications.

A student, getting to know the bases of natural sciences in school, is $9-12$ years of old. It is the time of a huge curiosity in relation to the world around, time to ask the questions, seek the rational answers and draw the conclusions. This openness to the world is a good base to adopt the knowledge transmitted in the right way.

\subsection{The difficulties occurring at the second educational stage}

\section{Almost half a century ago, Z. Batorowicz (1971)} listed a number of problems in the classes. There are, inter alia, the difficulties in using a map scale among them. The students may have a problem with imagining the actual distances and areas based on a map. This issue also related to the student's attempts to imagine a height above the sea level and the relative heights, as well as to the abilities to read a drawing of contour line. This happens even then, when a student uses the hypsometric maps, where the colours, used on a map, should reduce the difficulties. Starting the discussing a map with the students, besides explaining the concepts of scale or contour lines, an analysis of legend should also be emphasised by a teacher, as well as the conventionality of the map symbols used on a map (the notations) should draw the students' attention. According to the research undertaken by $Z$. Batorowicz, the problem was also with pointing out the directions on a map and globe.

In addition to these problems, W. Ostrowski (1990) notes that the students find it difficult to analyse an image projected from above, and, thus, lacking the third dimension. It can cause the problems with reading a map, on which such a way of projection is still used. Hence, a need to work on the spatial imagination appears, where the comparison of a map with the terrain is very helpful. Another problem may be connected with reading the relief features presented with the varying degrees of details (generalization) on the hypsometric maps at different scales.

In 2012, the staff of the Pedagogical University of Cracow conducted a survey among the teachers of natural science (M. Tracz, A. Świętek 2012). As an issue particularly difficult for the students, they indicated the work with a map very often, especially the concept of scale. It exhibits the scope of this problem and shows how important is a way of introducing the bases of cartography in primary school. Most of the difficulties are caused by the insufficient train of student's spatial imagination, so, one should exercise this skill repeatedly and regularly in order to improve. The conventional symbols, the so-called notations, can be illustrated with the help of relevant photographs or drawings, but reading the relief features on a map can be preceded by the constructions of models. When discussing the height or distance on a map, one should compare its contents with the terrain.

\section{Aids and instructional solutions supporting the natural science education}

In the process of natural science education in primary school, it is very important to develop the children's abstract thinking, which causes the stimulation of their spatial imagination. Let us, therefore, view the various types of teaching aids, which can be available for both, a teacher and a student.

\subsection{Atlases}

Both, when we are talking about the issues of cartography and topography, as well as throughout the whole course of teaching the natural science, it is necessary to use the atlases. It is very important, therefore, to pay the attention to cartographic solutions undertaken in the atlases for natural science, which may be helpful in a classroom and during an individual learning.

Poradnik młodego kartografa (A2) ${ }^{1}$ (The Guide of a young cartographer) is a supple-

\footnotetext{
1 The numbers in parentheses preceded by the letter $A$ refer to the list of atlases, which is included at the end of the text, while the numbers preceded by the letter $P$ refer to the list of textbooks.
} 


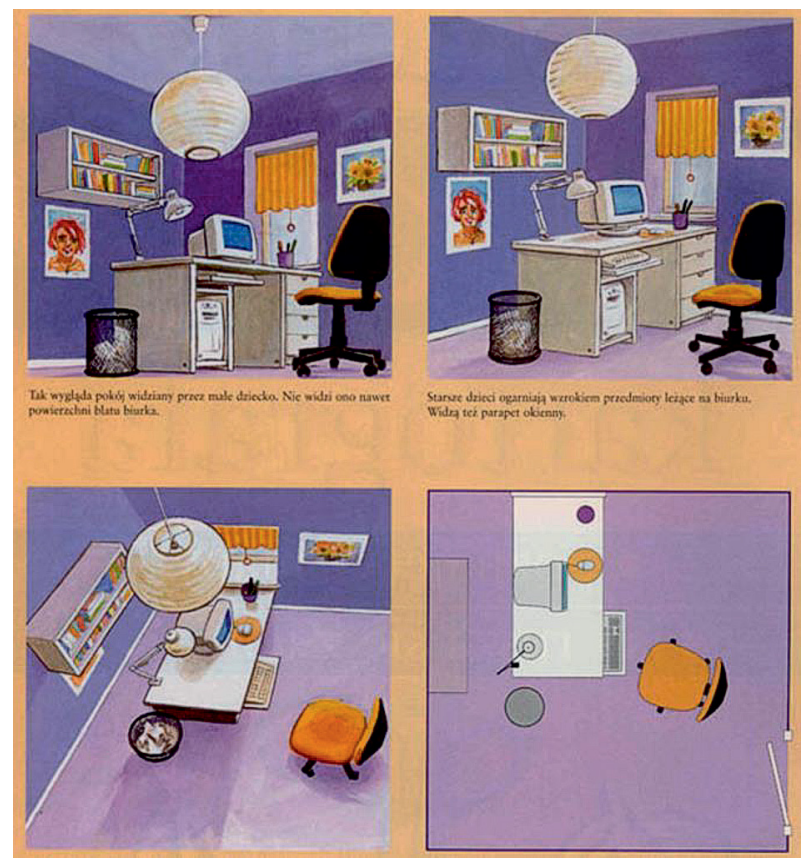

Fig. 1. The transition from the normal view to the projection (A2)

ment to the atlas edited by the publishing house Demart. It discusses some basic concepts in the scope of cartography and topography. The concept of scale, as shown on the example of room plan, is introduced in an interesting way. On the same figure a transition from the normal view to the projection from above (fig. 1) is shown. An aerial photo is also posted, as well as a map of the same area, which is helpful in clarifying the concepts of generalization and map legend. The impact of scale on the content of map is shown on the examples of maps at various scales with their legends.

Similar, but better solution, one can find in the atlas Przyroda. Atlas Polski. Wprowadzenie w świat mapy. Część pierwsza (Natural science. Atlas of Poland. Introduction to the world of map. Part one) edited by the Publishing House Żak (A3) (fig. 2). This scheme can be very useful to discuss a number of issues, including generalization, legend, distinguishing between the small and large scales. It also contains two maps of the same area, the topographic one at the scale of $1: 10,000$ and the landscape map at the scale of $1: 100,000$. The second part of publication issued by this publisher is an atlas of the world Przyroda. Atlas świata. Wprowadzenie w świat mapy, część druga (A4) (Natural science. Atlas of the world. Introduction to the world map. The second part) (A4). These atlases are very much focused on the correct interpretation of a map. One can find here the examples of map use, detailed overview of different map components, directions on a map and its scale, as well as the examples of tasks on each page. Very detailed explanations of the symbols used on maps, not only in the form of legend. New symbols are explained on photos and drawings.

A difficult issue is the teaching about the terrain relief. The authors of the atlases illustrate this issue with the help of examples of the maps depicting the same area, but using quite the different methods: shadings, contour lines and hypsometric colours. To show the effect of relief generalization, the maps of the same area in two scales were compiled. The crosssections showing the landscapes or surface relief along the chosen parallel or meridian were joined to the landscape maps and general geographical maps (A4). 


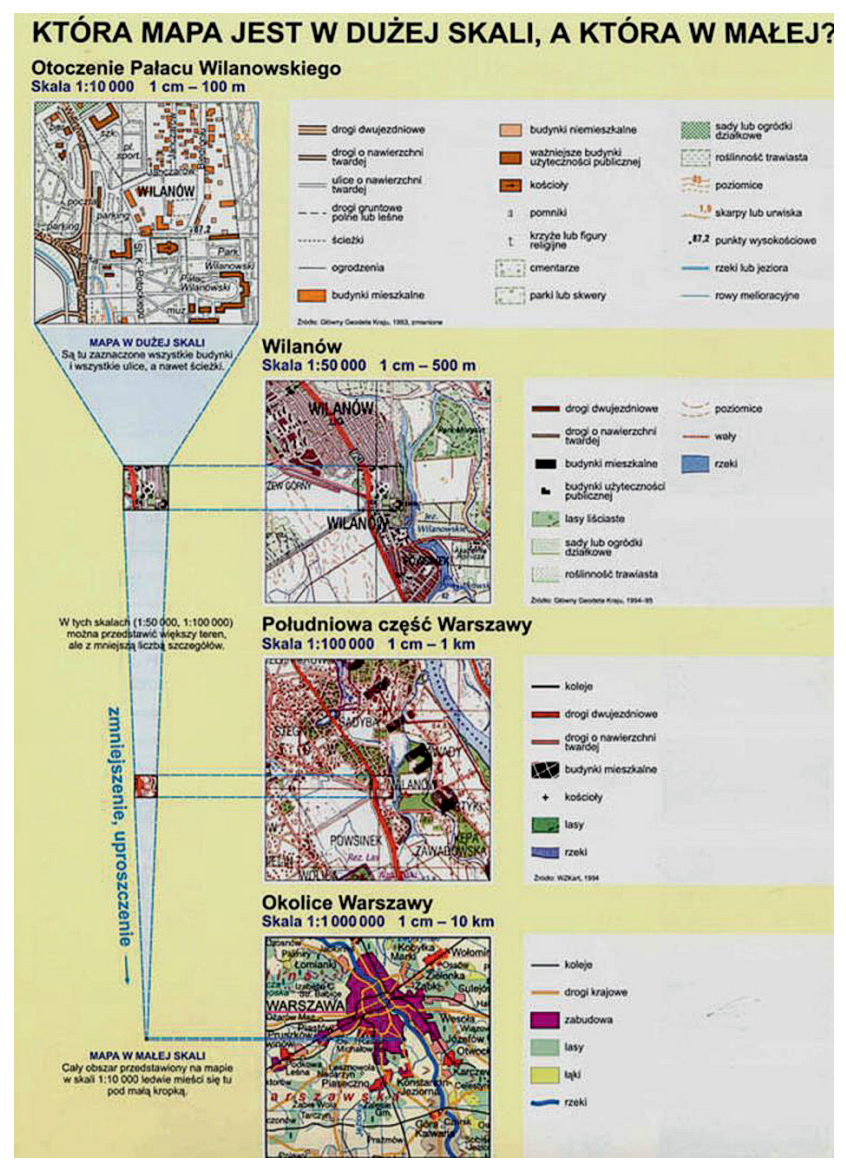

Fig. 2. The comparison of maps at different scales (A3)

A new atlas Nowy atlas. Przyroda. Świat wokół nas (A1) (A new atlas. Natural science. The world around us) (A1) edited by the Nowa Era publishing house enjoys a great popularity in the Polish schools. Many figures in this atlas have a high educational value, e.g., the comparison of the images with the plans of class and school, illustration of geographical directions on both, on a map and on a globe. The use of block-diagrams to show the different types of landscape and to compare with both the maps, a hypsometric one and a landscape map of the same area, is very popular.

The examples of maps, cross-sections and diagrams can be a good complement and extension of contents of the textbooks used in this or another school for both, the teacher and the student.

\subsection{Models}

Besides atlas and map, when teaching the cartography and topography, many other teaching aids could be indicated as very useful. The models make it easy to observe and understand the phenomena, influence on the spatial imagination. Making the models teaches the students to read a map precisely, promotes the knowledge of landforms.

The inductive and physical globes play an important role among the teaching aids. Being the models, they demonstrate the three-dimensionality of the entire globe. When discussing the geographical coordinates, their use is particularly significant, primarily, the inductive globe is useful for this. 
The teaching aids used for learning about the relief characters are equally important. The basic tool here can be a sandbox, in which the students could independently perform the models of these characters formed with the sand. Working with the plastic models facilitates the subsequent understanding of relief on a map. It will be available, if a model presents the particular geographical object (K. Tywoński 1983). Also, a plastic relief map, being a model of terrain relief, although, does not keep the natural proportions of the horizontal and vertical dimensions of relief forms, is suitable for the development of the skills, which are necessary for reading the hypsometric maps.

\subsection{Interactive teaching aids}

The Augmented Reality Sandbox is a very interesting and modern teaching aid based on the visualization of contour lines on the material, which is modifiable in the real time (http:// idav.ucdavis.edu/). While pouring the sand, someone forms therefrom the patterns, which are projected automatically by the contour lines and hypsometric colours. Because of this innovative method, it became possible to stimulate the imagination of a student, present to him the issues connected with the relief and its presentation on the maps. There are some films presenting the manner of operation and a user manual showing the instruction of AR Sandbox performance on the Internet. If we cannot construct our own "sandbox", it is worth to present one of such films to the students.

Today's students are accustomed to using the Internet in the process of learning, which can be easily used in the teaching of natural science in school. The geoportals may be helpful to discuss a number of topics (P. Pokojska, W. Pokojski 2013), for example, the geoportal of the General Directorate for Environmental Protection (containing, among others, a complete database of forms of environmental protection in Poland), the geoportal of the Head Office of Geodesy and Cartography, as well as the geoportals of the selected national parks. The richness of their contents offers the great opportunities for learning.

It is also advantageous to use the application called Google Earth in teaching about a map and its elements. In this program you can per- form the distance measurements, show the images of hills with their relative and absolute altitudes and terrain profiles. In the application called Google Maps you can compare a map with an aerial photo.

The aids described are very important due to their wide availabilities and possibilities of using, not only for school learning. By enabling these mapping services in education, children can become their users, more aware than they were before. Geoportals and mapping services should not replace the maps, but nowadays, the ability to use them is very useful.

\subsection{Books and games for the students interested in the world}

Encourage the students to seek self-knowledge. For this purpose can be used, inter alia, a book titled Przyroda. Pytania dzieci - odpowiedzi dorosłych (Natural science. Children's questions - adult's answers) (H. Rembertowicz 2004). When exploring the issues related to the cartography, it may be helpful to refer to the chapter "Map and space"; you can also use this book, when discussing the other topics during the natural science classes.

A book Mapy (The maps) by A. and D. Mizielińscy (2012) should also be recommended. The simplified maps, which are placed here, have a great educational value, because of the richness of information contained therein. With the vignettes placed on the maps, the small monographs on the selected countries from all over the world, as well as the Antarctic and the Arctic, are presented. We can find here the most important cities, tourist attractions, characteristic animals and plants, learn a lot about the culture and history. The children easily assimilate the knowledge passed with the help of simple drawings. As an addition to the book is Mapownik - czyli praktyczny kurs mazania po mapach (Map-case - that is a practical course of "smearing" the maps), by the same authors (A. and D. Mizielińscy 2013). A lot of interesting exercises are proposed here. A child may perform a map of an imaginary country, learn the names and positions of countries and continents, as well as the appearances of flags. There is a task here to draw a map of the nearest neighbourhood, along with its legend. The steps are used in this exercise as the denominator 
of scale, so that a child can easily compiled a map by himself.

One should also pay the attention to the geographical games that appear on the Polish market. The most recent is the "KartoGRAfia" (fig. 3), which - as we can read in the manual - "takes you on an exciting race for unknown areas on the occasion of learning how to read the maps". The game consists of a set of cards marked with the cartographical symbols, with the help of which the objects are presented on the topographical and general geographical maps. Each card contains 12 symbols, but only one of them is repeated on any two cards. The game teaches the perceptiveness and helps to gain the skills necessary for interpreting the maps.

\section{The new core curriculum}

Introduced in 2009, the new core curriculum is cumulative. This means that the knowledge from the previous stage is necessary for a student on the next levels of education. The content, one time transmitted, is not repeated, unless the issue is expanded.

The subject "natural science" is realized in the Polish primary school at the second stage of education, that is the period of grades 4 through 6 . The knowledge passed at this period is the basis for education of a young man. The practical applications of gained messages should be presented by a teacher, who must teach the students how to use the different sources of information. The requirements must be adjusted to the individual possibilities of every student.

The authors of the curriculum on several occasions pay the attention that, when introducing some new issues, a teacher should begin the next topic by discussing the objects and phenomena occurring in the immediate vicinity, because these phenomena and objects are well-known to the students. Then, a teacher should broaden the horizon of students' knowledge about new, often more remote areas.

The core curriculum for the second stage of education (grades 4 through 6 ) does not contain too much information in the scope of cartography and topography. The elements of the first section titled Ja i moje otoczenie (Me and my surroundings) serve as an introduction to this content. A student learns here the role of human senses, as well as the applicable instruments

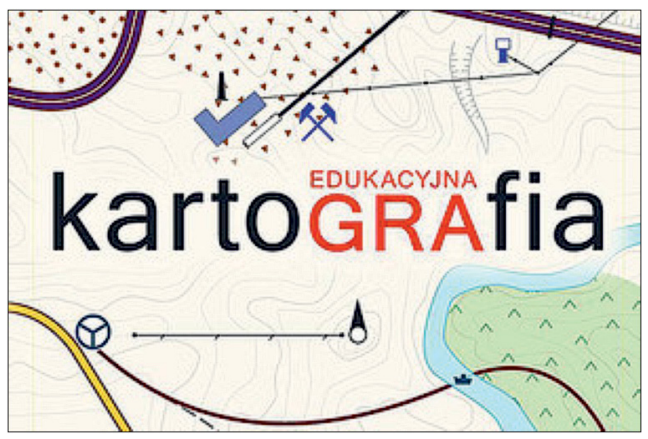

Fig. 3. Educational game KartoGRAfia (Cartography)

that help in studying the nature surrounding him. It is recommended to carry out the individual observations.

The second section of the curriculum Orientacja $w$ terenie (Field orientation) - is dedicated to the field orientation in accordance with the title, as well as to the maps. As the specific criteria listed the capacities of using the gnomon and compass, map orientation in the field, determining the location of place, which is observed, and the objects surrounding it on the topographical map and in the field. To perform these actions, the skill of using the map legend is indispensable. Every student should also be able to perform the measurements, estimate the distances and heights in the field. The concept of scale is not included in the core curriculum for natural science, however, among the requirements is the bar scale using: a bar scale, after all, is a graphical presentation of scale. Scale has been included in the core curriculum of mathematics for this level of education.

A student, completing the second phase of education, should also distinguish the relief forms in a reality and on a model, indicate them on the contour line map, as well as recognize the lowlands, highlands and mountains on the hypsometric map.

A section Lądy i oceany (Lands and oceans) includes very important elements of cartographical knowledge. This section refers to the geographical coordinates, hemispheres, main directions, determining the positions of continents and oceans in terms of selected meridians and parallels. A student should be able to indicate them on a map, as well as on a globe. 
The new core curriculum for natural science is talking indeed about using the contour line maps, as well as about using the hypsometric ones, but there are no instructions how to discuss them. It is lacking a clarification for the concept of generalization.

The new core curriculum contains a number of issues that, although, do not apply directly to the cartography and topography, can be discussed in a much more accessible way, using a map or globe. These are the contents concerning, among other things, the protection of nature, landscapes and geographical discoveries. Map and globe should accompany a student during the majority of instruction in natural science, so that he would be aware of how much information can be found with their help.

\section{The cartographic and topographic contents of the textbooks and the core curriculum}

The introduction of new core curriculum was the reason for the issue of new textbooks adopted to this curriculum.

The books for the fourth grade came into effect in 2012, for the fifth and sixth grades in the next years, 2013 and 2014. Nowa Era publishg house has marketed two series of books for natural science: Na tropach przyrody (On the trails of nature) (P1, P2, P3) and Tajemnice przyrody (The secrets of nature) (P4, P5, P6).

\subsection{The comparison of the series $\mathrm{Na}$ tropach przyrody and Tajemnice przyrody}

The main difference between the series of textbooks mentioned above (fig. 4 and 5 ) is the content layout. More issues on cartography and topography are discussed in the textbook Tajemnice przyrody 4 (The Secrets of nature 4) (P4) than in the textbook Na tropach przyrody 4 (On the trails of nature 4) (P1) and thus, it is possible to use the maps already in the fourth grade. The consequence of such a material selection is the greater range of content on the maps in the next year of education in the textbook $\mathrm{Na}$ tropach przyrody 5 (On the trails of nature 5) (P2) than in the textbook Tajemnice przyrody 5 (The secrets of nature 5) (P5). A scope of basic information in both the books for the VIth class (P3, P6) is quite comparable. However, the book Na tropach przyrody 6 (On the trails of nature 6$)$ (P3) contains a valuable additional content.

An undoubted advantage of a series $\mathrm{Na}$ tropach przyrody (On the trails of nature) is the notion of generalization, which is taken into account - an issue, which is beyond the core curriculum, identifying the practical ways of using the maps and establishing in the textbooks for the fifth and sixth grades (P2, P3) the knowledge acquired earlier. Another advantage is a very inventive presentation of parallels and meridians - the concepts, which seemed to be abstract to the students - using, e.g., an orange. Noteworthy are also the additional materials placed in the textbooks. In the sixth grade, they are, e.g., the proposals of exercises relying on reading the geographical coordinates and on a field lesson, during which the students have to perform a map of the nearest neighbourhood.

On the other hand, in a series Tajemnice przyrody (The secrets of nature) one can find the illustrations, better depicting the notions than in a series Na tropach przyrody (On the trails of nature). The good examples are the chapters on hypsometric maps. In the textbook Tajemnice przyrody 5 (P5) the first illustrations of this issue are more demonstrative (fig. 6A), than in the corresponding handbook of the second series (P2, fig. 6B).

In addition to the hypsometric maps, the block-diagrams are provided to illustrate the use of hypsometric colours in the both series of textbooks. Discussing the landforms, a sand model execution is proposed to the students in the book Na tropach przyrody 4 (P1), while an instruction for carrying out the levelling is given in the book Tajemnice przyrody 5 (P4).

The content layouts are similar in the both books. On the other hand, their systems are different and not always logical. It can be demonstrated by analysing the issues of geographical directions. In the textbook Na tropach przyrody 4 (P1), when discussing the directions, henceforth, the concept of geographical north is introduced first, a then, the ways of its determining with the help of gnomon and compass, however, it is not mentioned, that a compass determines only the magnetic north, not geographical one. The other main and intermediate directions are discussed only at the end. In the textbook Tajemnice przyrody 4 (P4), the 

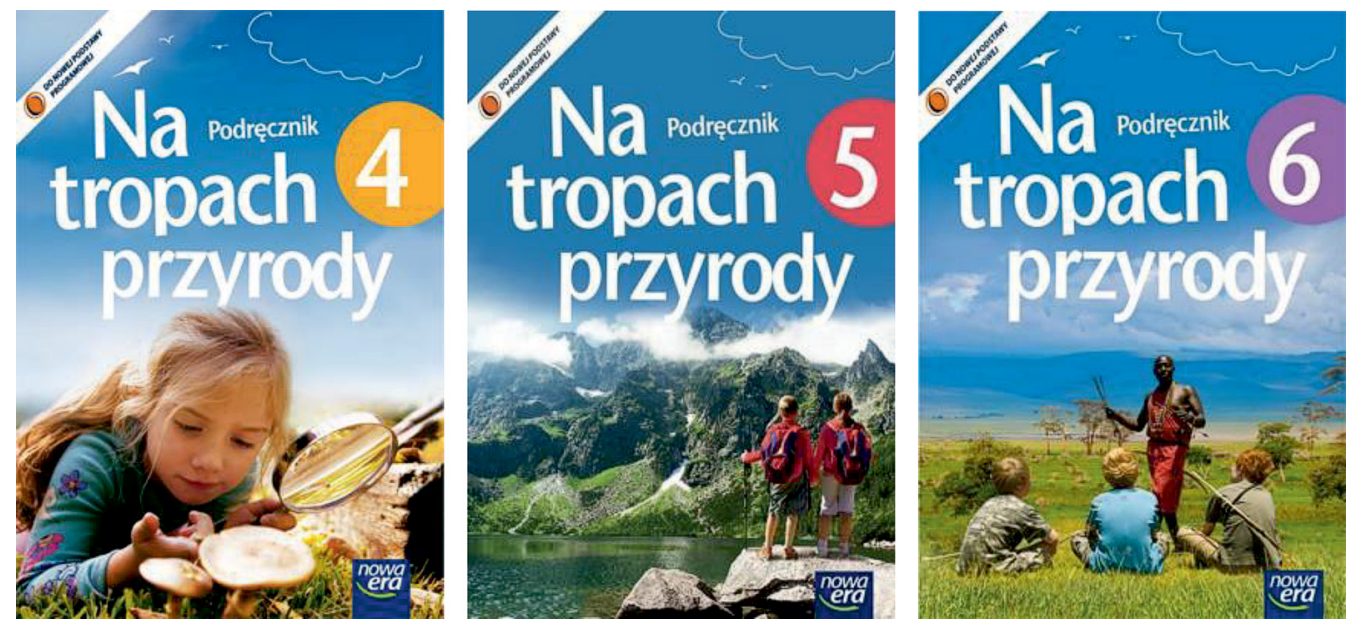

Fig. 4. Covers for a series of textbooks titled Na tropach przyrody (On the trails of nature) (P1, P2, P3)
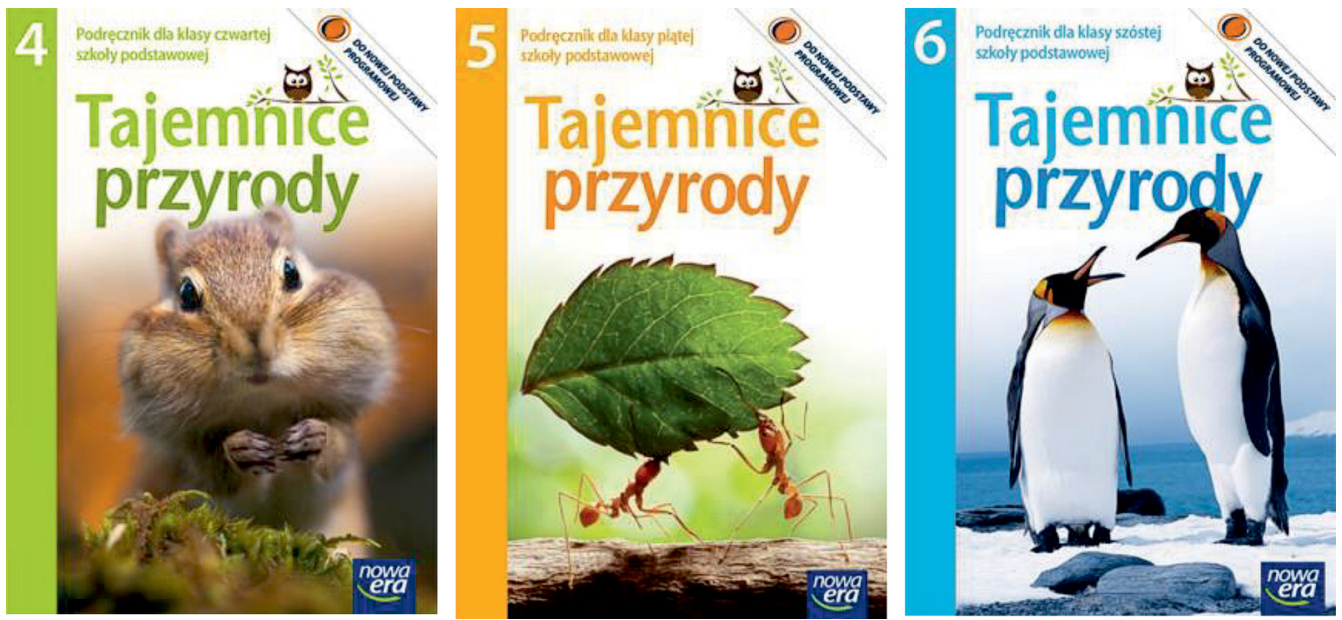

Fig. 5. Covers for a series of textbooks titled Tajemnice przyrody (The secrets of nature) (P4, P5, P6)

methods of determining the directions are discussed first, and then their notion is introduced. Much more space is devoted to the discussion on the notion of scale, as well as to the exercises connected with this concept.

The legend and signs on a map are described in the both books similarly. In the textbook Tajemnice przyrody 4, the point signs are called "the small pictures", but the linear ones - "the multi-coloured lines" (P4, p. 39). On the other hand, in the handbook titled Na tropach przyrody 5, the point signs are called "the symbols" and the linear ones - "the lines of certain colours"
(P2, p. 11). The signs of surface are called everywhere "the coloured spots".

When elaborating the textbook titled $\mathrm{Na}$ tropach przyrody, the authors tried to indicate more practical ways of using the maps in practice, than in the case of the textbook Tajemnice przyrody. However, in this second series the links to Google Maps are placed. Unfortunately, the maps are used in both the books primarily when discussing the landscapes. The students should be more encouraged to use the atlases and maps, because the lack of incentives may result here in the uneducated basic skills or 


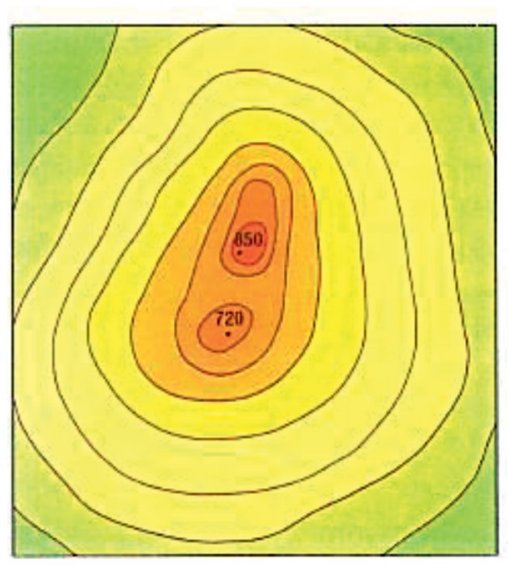

A

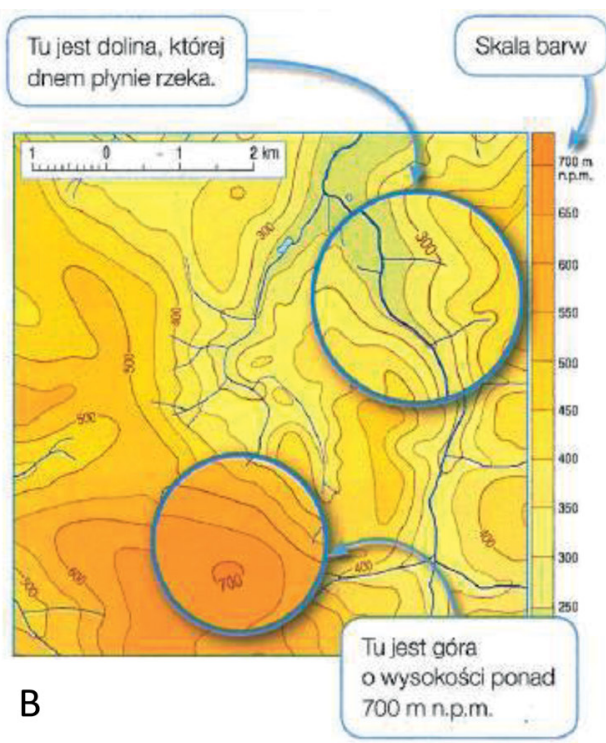

Fig. 6. Hypsometric map: A - in the textbook Tajemnice przyrody 5 (The secrets of nature 5) (P5), $B-$ in the textbook Na tropach przyrody 6 (On the trails of nature 6) (P3)

undeveloped core competencies essential at the later stage of education.

\subsection{The contents of the textbooks and the core curriculum}

A series titled Tajemnice przyrody (The secrets of nature) meets all the requirements of the core curriculum in the scope of cartography and topography, while the textbook Na tropach przyrody (On the trails of nature) (P1, P2) most of these requirements. The textbook contents are very often limited, unfortunately, only to the core curriculum.

The issues related with a way of determining the directions have been discussed in the textbooks for the fourth grade, at the same time, in the textbook titled Na tropach przyrody 4 (P1), the basic information necessary for distinguishing the landforms has been also discussed. In the textbook Tajemnice przyrody 4 (P4), these issues are extended to include the basic knowledge on map orientation and legend, which allows to use this information during the field activities. Unfortunately, a teacher working with the textbook Na tropach przyrody 4 (P1) does not have such a possibility. For this reason, the implementation of some issues on the basis of this book may be more difficult.

The textbooks for the fifth grade differ from each other in such a way, that a book $\mathrm{Na}$ tropach przyrody 5 (P2) introduces the concept of map, while a book from the second series extends a scope of knowledge from the previous grade. The bar scale, collection of field data, contour line map and hypsometric one are discussed in both the handbooks.

In both the series for the sixth grade, the topics on coordinates and geomagnetism from the core curriculum, as well as those on using a globe, are overlapped with each other and they are adequate to the core curriculum.

One should pay the attention to arranging the content of a series Tajemnice przyrody, which is much better organized. The system of knowledge applied here allows for better and fuller using a map in teaching the natural science already from the fourth grade. It is right to place the contents for determining the position of an object on a map or globe at the beginning of a textbook for the sixth grade. Unfortunately, in both the books, when discussing the topics on core curriculum, the errors are visible, e.g., in the form of vague definitions. 


\section{Conclusions}

Natural science education in school is very important, because on the level of this education depends the fact whether the students of higher levels of education, and then the students of the Universities, will be able to think logically, combine the facts, deduce and observe the world around them.

The analysis of new core curriculum allowed for a critical assessment of its content in the scope of cartography and topography. One should well evaluate an emphasis on the development of practical skills, such as field data collecting, using of a scale, determining the directions, field bearing, reading the maps: a contour line map and hypsometric one. These issues are included into the textbooks approved for school use. These textbooks have the attractive graphical layouts, but sometimes some stumbles happen. For example, in both the series, a theory for the concept of geographical directions was introduced after discussing the practical applications.

\section{Literature}

Batorowicz Z., 1971, Mapa w nauczaniu geografii. Warszawa: Państwowe Zakłady Wydawnictw Szkolnych.

Birch A., Malim T., 2001, Rozwój poznawczy. In: Psychologia rozwojowa $w$ zarysie: od niemowlęctwa do dorosłości. 4th ed. Warszawa: Wydawnictwo Naukowe PWN.

Mizielińska A., Mizieliński D., 2012, Mapy. Obrazkowa podróż po lądach, morzach i kulturach świata. Warszawa: Wydawnictwo Dwie Siostry.

Mizielińska A., Mizieliński D., 2013, Mapownik - czyli praktyczny kurs mazania po mapach. Warszawa: Wydawnictwo Dwie Siostry.

Ostrowski W., 1990, Mapa, jej własności i percepcja. In: Dydaktyka geografii w szkole podstawowej. Ed. A. Dylikowa. Warszawa: Wydawnictwa Szkolne i Pedagogiczne, pp. 128-142.

Pokojska P., Pokojski W., 2008, Wirtualny globus Google Earth. „Geografia w Szkole” R. 61, nr 1, pp. 58-64.

Pokojska P., Pokojski W., 2013, Geoportal krajowy ważnym źródłem informacji przestrzennej o środowisku geograficznym w procesie edukacji. „Edukacja Biologiczna i Środowiskowa” Nr 1, pp. 42-50.

Rembertowicz H. (ed.), 2004, Przyroda. Pytania dzieci - odpowiedzi dorosłych. Warszawa: Szkoła Wyższa Przymierza Rodzin.

Romer E., 1908, Geografia dla klasy pierwszej szkót średnich z atlasem geograficznym. Lwów: Nakła-
The analysis of developmental psychological aspects and some difficulties in teaching, observed in the grades 4 through 6 of primary school, allow to conclude that the main obstacle to knowledge and education may be the abstract thinking insufficiently developed at this age. As a consequence, there are some problems with the spatial imagination, which is necessary for working with a map. A skilful using of teaching aids allows to level or even eliminate these difficulties. An important role is played by the field exercises, which allow the students to work individually.

Teaching the basics of cartography and topography from an early age is very important, but developing the ability to use a map requires the continuous exercises. Working with a map helps to develop not only the practical skills, but also the student's attitudes having a positive impact on the development of such qualities as conscientiousness, accuracy and patience; it also has an invaluable impact on the spatial imagination.

dem Towarzystwa Nauczycieli Szkół Wyższych. Reprint: Warszawa - Wrocław: Nowa Era, 2008.

Rozporządzenie Ministra Edukacji Narodowej z dnia 23 grudnia 2008 roku w sprawie podstawy programowej wychowania przedszkolnego oraz kształcenia ogólnego w poszczególnych typach szkół. 2009, „Dziennik Ustaw” Nr 4, 15 stycznia, poz. 17. Podstawa programowa z komentarzami. Tom 5 . Edukacja przyrodnicza w szkole podstawowej, gimnazjum i liceum, pp. 28-72.

Tracz M., Świętek A., 2012, Nauczyciele o nauczaniu przyrody w szkole podstawowej. „Geografia w Szkole", R. 65, nr 4, pp. 15-19.

Trojan K., 2014, Geoportale, czyli geografia w praktyce. „Geografia w Szkole” R. 67, nr 2, pp. 39-42.

Tywoński K., 1983, Pomoce dydaktyczne do geografii. Warszawa: Wydawnictwa Szkolne i Pedagogiczne. Wilczyńska-Wołoszyn M., 1990, Wykorzystanie map w procesie nauczania geografii. In: Dydaktyka geografii w szkole podstawowej. Ed. A. Dylikowa, Warszawa: Wydawnictwa Szkolne i Pedagogiczne, pp. $142-170$.

\section{Atlases}

A1. Nowy atlas. Przyroda. Świat wokół nas. Eds. K. Chariza, S. Curyło, J. Romanowska, 3rd ed., Warszawa: Nowa Era, 2012. 
A2. Poradnik młodego kartografa. Supplement to the Atlas do przyrody - świat w porach roku. Eds. M. Wieczorek, B. Byer, A. Banach, Warszawa: Demart, 2003.

A3. Przyroda: wprowadzenie w świat mapy. Cz. 1, Atlas Polski. H. Górski, M. Wilczyńska-Wołoszyn, Warszawa: „Żak” - Wydawnictwo Edukacyjne Zofii Dobkowskiej, 2001.

A4. Przyroda: wprowadzenie w świat mapy. Cz. 2, Atlas świata. H. Górski, M. Wilczyńska-Wołoszyn, Warszawa: „Żak” - Wydawnictwo Edukacyjne Zofii Dobkowskiej, 2002.

\section{Textbooks}

P1. Braun M., Grajkowski W., Więckowski M., 2012, Na tropach przyrody 4 (On the trails of nature 4).
Warszawa: Nowa Era.

P2. Braun M., Grajkowski W., Więckowski M., 2013, Na tropach przyrody 5 (On the trails of nature 5). Warszawa: Nowa Era.

P3. Braun M., Grajkowski W., Więckowski M., 2014, Na tropach przyrody 6 (On the trails of nature 6). Warszawa: Nowa Era.

P4. Marko-Worłowska M., Szlajfer F., Stawarz J., 2012, Tajemnice przyrody 4 (The secrets of nature 4). Warszawa: Nowa Era.

P5. Kozik R., Szlajfer F., Ślósarczyk J., 2013, Tajemnice przyrody 5 (The secrets of nature 5). Warszawa: Nowa Era.

P6. Marko-Worłowska M., Szlajfer F., Stawarz J., 2014, Tajemnice przyrody 6 (The secrets of nature 6). Warszawa: Nowa Era. 